\title{
Review
}

\section{The Role of Breast Cancer Stem Cells in Metastasis and Therapeutic Implications}

\author{
Marco A. Velasco-Velázquez, ${ }^{* \dagger}$ \\ Vladimir M. Popov, ${ }^{\dagger}$ Michael P. Lisanti, ${ }^{\ddagger}$ \\ and Richard G. Pestell ${ }^{\dagger}$ \\ From the Department of Pharmacology, ${ }^{*}$ Faculty of Medicine, \\ National Autonomous University of Mexico (UNAM), Mexico City, \\ Mexico; and the Departments of Cancer Biology ${ }^{\dagger}$ and Stem Cell \\ Biology and Regenerative Medicine, ${ }^{\neq}$Kimmel Cancer Center, \\ Thomas Jefferson University, Philadelphia, Pennsylvania
}

\begin{abstract}
Cancer stem cells (CSCs) possess the capacity to self-renew and to generate heterogeneous lineages of cancer cells that comprise tumors. A substantial body of evidence supports a model in which CSCs play a major role in the initiation, maintenance, and clinical outcome of cancers. In contrast, analysis of the role of CSCs in metastasis has been mainly conceptual and speculative. This review summarizes recent data that support the theory of CSCs as the source of metastatic lesions in breast cancer, with a focus on the key role of the microenvironment in the stemness-metastasis link. (Am J Patbol 2011, 179:2-11; DOI: 10.1016/j.ajpath.2011.03.005)
\end{abstract}

Cancer stem cells (CSCs) are tumor cells that possess the capacity to divide asymmetrically, producing one stem cell (self-renewal) and one progenitor cell that is able to generate heterogeneous lineages of the cancer cells that comprise tumors. CSCs in human breast tumors were initially identified in 2003 by $\mathrm{Al}$-Hajj et al, ${ }^{1}$ who discovered a cellular population characterized by the cell-surface markers CD44 ${ }^{+} / \mathrm{CD} 24^{- \text {llow }} / \mathrm{ESA}^{+}$and lack of expression of CD2, CD3, CD10, CD16, CD18, CD31, CD64, and CD140b (lineage ${ }^{-}$). As few as 200 of these cells were able to form tumors when xenotransplanted into NOD/SCID mice, whereas tens of thousands of other cells could not. ${ }^{1}$ The tumors generated recapitulated the phenotypic heterogeneity of the parental tumor, containing a minority of $\mathrm{CD}_{4} 4^{+} / \mathrm{CD} 24^{-/ \text {low }} /$ lineage ${ }^{-}$cells that can be serially passaged to form new tumors. ${ }^{1}$ The CD44 ${ }^{+} /$CD24 $^{-}$phenotype has been used extensively to identify and isolate breast cancer cells with increased tumorigenicity.
Putative breast CSCs have also been isolated from patient samples after in vitro propagation and from breast cancer cell lines, through their ability to proliferate in suspension as nonadherent spheres (mammospheres). ${ }^{1-4}$ Because the capacity to form mammospheres is increased in early progenitor/stem cells, this system has been widely used as an indirect measurement of the number of cells with self-renewal capability. ${ }^{5,6}$ In accord with in vivo data, mammospheres from breast cancer cells are enriched in cells with the $\mathrm{CD} 44^{+} / \mathrm{CD} 24^{- \text {/low }}$ phenotype, ${ }^{2,3}$ and these cells retain tumor-initiating capability when injected into NOD/SCID mice; however, only a fraction of $\mathrm{CD} 44^{+} / \mathrm{CD} 24^{- \text {/low }}$ cells isolated from mammospheres are able to form secondary mammospheres. ${ }^{2}$ Consistent with these findings, cancer cell lines that are enriched in $\mathrm{CD} 44^{+} / \mathrm{CD} 24^{- \text {llow }}$ cells are not more tumorigenic than cell lines that contain only $5 \%$ of cells with that phenotype, ${ }^{3}$ indicating that only a subgroup of $\mathrm{CD} 44^{+} / \mathrm{CD} 24^{- \text {llow }}$ cells are self-renewing.

Because only a subpopulation of $\mathrm{CD} 44^{+} / \mathrm{CD} 24^{-}$retain self-renewal capability, other markers for human breast CSCs have been investigated. Activity of the aldehyde dehydrogenase (ALDH) family of cytosolic isoenzymes is in-

Supported in part by PASPA-UNAM (Programa de Apoyos para la Superación del Personal Académico-Universidad Nacional Autónoma de México) (M.A.V.-V.) and the NIH (grants R01CA070896, R01CA075503, R01CA107382, R01CA132115, and R01CA086072 to R.G.P. and R01CA120876 to M.P.L.). The Kimmel Cancer Center was supported by an $\mathrm{NIH}$ cancer center core grant (P30CA56036 to R.G.P.). This project is funded in part from the Marian C. Falk Medical Research Trust and a grant from the Pennsylvania Department of Health (R.G.P.).

Accepted for publication March 15, 2011.

CME Disclosure: The authors did not disclose any relevant financial relationships.

A guest editor acted as editor-in-chief for this manuscript. No person at Thomas Jefferson University or Albert Einstein College of Medicine was involved in the peer review process or final disposition of this article.

Address reprint requests to Richard G. Pestell, M.D., Ph.D., Department of Cancer Biology, Thomas Jefferson University, 233 S. 10th St., Philadelphia, PA 19107; or Marco A. Velasco-Velázquez, Ph.D., Departamento de Farmacología, Facultad de Medicina, Universidad Nacional Autónoma de México, Apdo. Postal 70-297, Ciudad Universitaria, México D.F. 04510, Mexico. E-mail: richard.pestell@jefferson.edu or marcovelasco@unam.mx. 
creased in human hematopoietic stem cells, as well as in cancer stem cells of multiple tissues. ${ }^{7,8}$ ALDH has been identified as a breast CSC marker. Breast tumor cells positive for ALDH activity were able to generate tumors in NOD/ SCID mice with phenotypic characteristics resembling the parental tumor, suggesting that the $\mathrm{ALDH}^{+}$pool contains the CSC population. ${ }^{9-11}$ Breast cancer cells with the $\mathrm{CD}_{4}{ }^{+} / \mathrm{CD} 4^{-} / \mathrm{ALDH}^{+}$phenotype were more tumorigenic than $\mathrm{CD}_{4} 4^{+} / \mathrm{CD} 24^{-}$or $\mathrm{ALDH}^{+}$cells, with as few as 20 cells being sufficient to generate tumors in mice. ${ }^{9}$

In murine models, other cell markers have been used to identify breast CSCs, including CD24, ${ }^{12-14}$ CD133, ${ }^{4}$ and stem cell antigen-1 (SCA-1). ${ }^{12,15}$ For example, in MMTV-Neu oncogene-induced mammary tumors, CSCs were found exclusively in either $\mathrm{CD} 24^{+} / \mathrm{Sca} 1^{+}$or $\mathrm{CD} 24^{+} /$ Sca1- ${ }^{-}$populations. ${ }^{12}$ In MMTV-Wnt1 mammary tumors, $\mathrm{CD}_{24}{ }^{+} / \mathrm{Thy}^{+}$fraction was highly enriched for cells capable of regenerating new tumors, ${ }^{13}$ whereas the $\mathrm{CD}^{2} 4^{+}$/ $\mathrm{CD}^{2}{ }^{+}$fraction was enriched for CSCs in tumors from Brca1-deficient mice. ${ }^{14}$ One possibility is that these cells with different immunophenotypes represent different origins of breast cancer stem cells. The CD $44^{+} / \mathrm{CD} 24^{-}$ population most likely represents basal breast cancer stem cells, and cells with the $\mathrm{CD} 24^{+} / \mathrm{CD} 29^{+}$signature most likely originate from the mammary luminal progenitor cells. Accordingly, human breast cancer cell lines with high $\mathrm{CD} 44^{+} / \mathrm{CD} 24^{-}$cell numbers display a basal/mesenchymal phenotype, but noninvasive luminal cell lines lack this population. ${ }^{16}$

The finding that a subset of cells from breast tumors are more tumorigenic than the other cells and that these cells express stem cells markers and divide asymmetrically supports the existence of CSCs. Nonetheless, different types of experimental data are hard to reconcile with the CSC hypothesis as the sole mechanism involved in tumor progression and therapy resistance. ${ }^{17}$ Substantial bodies of evidence in support of major roles of CSCs in the initiation, maintenance, resistance to therapeutic regimens, and clinical outcome of breast tumors have been reviewed recently. ${ }^{18,19}$ In contrast, although several authors have proposed the hypothesis that CSCs may be responsible for the development of secondary tumors, ${ }^{20-22}$ the analysis of the role of CSCs in breast cancer metastasis has been mainly conceptual and speculative. Because most deaths of breast cancer patients are from metastasis, a better understanding of the mechanisms of tumor metastasis is important for developing more effective therapeutic strategies.

In this review, we summarize recent reports providing support for the idea that CSCs are key players in metastasis; we also point out and discuss the consequent therapeutic implications.

\section{Are CSCs the Source of Metastatic Lesions in Breast Cancer?}

Only $0.02 \%$ to $0.1 \%$ of the cancer cells that reach the circulation can develop macrometastases. ${ }^{23}$ However, the identification of the small subset of cancer cells that can complete the metastatic cascade has remained elu- sive. CSCs are candidates for the subset of cancer cells that give rise to metastases because, according to the CSC hypothesis, only CSCs will initiate and sustain tumor growth. Consequently, several authors have proposed a model in which CSCs appear as the active source of metastatic spread. ${ }^{20-22}$ Originally, such a model was supported only by indirect evidence. For example, many of the factors known to govern hematopoietic stem cell migration also play an important role in metastasis (reviewed by $\mathrm{Li}$ et $\mathrm{al}^{21}$ ), and a minor population of cancer cells programmed to metastasize to specific organs was identified by functional genomics. ${ }^{24}$ At present, several lines of evidence support a model in which CSCs contribute to the metastatic dissemination of solid tumors. In the case of breast cancer, both clinical and basic studies have shown correlative as well as direct evidence for the role of CSCs in metastasis. Clinical evidence that suggest a relationship between CSCs and metastasis includes the following observations:

1. A high percentage of $\mathrm{CD} 44^{+} / \mathrm{CD} 24^{- \text {llow }}$ tumor cells in breast primary tumors correlated with the presence of distant metastases, particularly osseous metastases. ${ }^{25}$

2. A subpopulation of circulating tumor cells from metastatic breast cancer patients expressed stem cell markers. ${ }^{26,27}$

3. The majority (71\%) of tumor cells in early bone marrow metastases expressed the $\mathrm{CD} 44^{+} / \mathrm{CD} 24^{-}$ phenotype. ${ }^{28}$

4. Pleural metastases from breast cancer patients were highly enriched for a CD $44^{+} / \mathrm{CD} 24^{- \text {/low }}$ subpopulation. ${ }^{29}$ All of the patients who were studied had already received chemotherapy, which highlights the link between chemoresistance of CSCs (reviewed by Liu and Wicha, ${ }^{19}$ Dean, ${ }^{30}$ and Lacerda et $\mathrm{al}^{31}$ ) and metastasis.

5. A gene signature of invasiveness, generated by comparing the gene expression profile of $\mathrm{CD}_{4} 4^{+} /$ CD24-/low tumorigenic breast cancer cells with that of normal breast epithelium, was strongly associated with metastasis-free survival. ${ }^{32}$

6. Expression of the stem cell marker ALDH in samples of inflammatory breast cancer correlated with the development of distant metastases and decreased survival. ${ }^{11}$ In other studies, however, ALDH prevalence was not a strong predictor of cancer stage or metastasis. ${ }^{33-35}$ This discrepancy can be explained on the basis of ALDH isoforms. The ALDH isoform usually thought to be responsible for the ALDH activity in CSCs is ALDH1A1. Recently, however, it was reported that $A L D H 1 A 3$ is the main isoform responsible for ALDH activity in breast CSCs and that its expression can be used as a specific marker for breast CSCs. ${ }^{35}$ ALDH1A3 expression in human breast cancer samples correlated significantly with tumor grade, metastasis, and cancer stage, showing that CSC prevalence is directly associated with metastasis. ${ }^{35}$

The clinical association between phenotypic characteristics of CSCs and the formation of breast cancer me- 
tastases has led to studies using mouse metastasis models to investigate whether CSCs have the ability to invade, home to specific organs, and proliferate at metastatic sites. These models, in which cancer cells are allowed to adhere, invade, and proliferate at multiple sites with different microenvironments, have provided direct evidence of the metastatic potential of breast CSCs and have indirectly suggested the mechanisms involved.

In experimental metastasis assays, cancer cells are directly injected into the circulation of immunodeficient mice. The number of metastases directly correlates with the metastatic ability of the injected cells. ${ }^{24,36}$ Intracardiac injection of 100,000 tumorigenic $\mathrm{ALDH}^{+}$cells from breast cancer cell lines into NOD/SCID mice generated multiple metastases at distinct organs (bone, muscle, lung, and soft tissue) that recapitulated the heterogeneity of the initial tumor. ${ }^{10,11}$ In contrast, the injection of unseparated cells or $\mathrm{ALDH}^{-}$cells produced, respectively, only one metastasis per mouse or occasional metastases limited to lymph nodes. ${ }^{10,11}$ In these studies, only the $\mathrm{ALDH}^{+}$and the unseparated populations were tumorigenic when injected into mammary fat pads, indicating that the metastatic ability is predominantly mediated by CSCs contained in the $\mathrm{ALDH}^{+}$population.

Bloodstream injections do not fully recapitulate human breast cancer progression, however. To further study the role of breast CSCs in metastasis, Liu et al ${ }^{37}$ used tumor xenograft models that develop spontaneous metastases. In their study, fresh specimens from various types of human breast cancer were collected. The cancer cells were separated into defined subsets (ie, CSCs versus non-stem cancer cells), transduced with lentiviral vectors encoding optical reporter fusion genes, and implanted into mice. The reporter genes expressed bioluminescent and fluorescent proteins, allowing the detection of as few as 10 cells under in vivo bioluminescent imaging, as well as ex vivo isolation for further analysis or profiling. In this way, early tumor growth and the activities of defined subsets of human breast cancer cells could be monitored. CSCs were isolated based on the expression of the $\mathrm{CD} 44^{+} / \mathrm{CD} 24^{- \text {/low }}$ phenotype; in accord with previous reports, ${ }^{1} \mathrm{CD}_{4} 4^{+} / \mathrm{CD} 24^{- \text {llow }}$ cells were tumorigenic, whereas $\mathrm{CD}_{44^{-}} / \mathrm{CD} 24^{-}$cells were not. ${ }^{37}$ Mammary fat pad implantation of CSCs from triple-negative human breast tumor samples produced spontaneous lung metastasis in $100 \%(73 / 73)$ of mice. The lung metastatic cells shared a similar CD44 expression profile with the parental cell line (17\% to $30 \%)$, regenerated tumors on implantation into mammary fat pads, and produced metastases at multiple sites (liver, bone, and spleen) after intravenous injection. ${ }^{37}$

Tumorigenic assays with sorted $\mathrm{CD} 44^{+} / \mathrm{CD} 24^{- \text {llow }}$ or CD44-/CD24-llow populations from lung metastases showed that only $\mathrm{CD} 44^{+} / \mathrm{CD} 24^{-/ 10 w}$ cells could grow tumors that can be serially passaged. ${ }^{37}$ In accord with these results is the report of Croker et $\mathrm{al}^{38}{ }^{38}$ who found that inoculations of breast cancer cells with a stem cell phenotype $\left(\mathrm{ALDH}^{\mathrm{high}} / \mathrm{CD}_{4} 4^{+} / \mathrm{CD} 24^{-}\right.$or $\mathrm{ALDH} \mathrm{H}^{\text {high }} / \mathrm{CD} 44^{+} /$ $\mathrm{CD} 133^{+}$) displayed increased tumorigenicity and produced more experimental and spontaneous metastases than the non-stem cancer cells. Although both subpopu- lations of cells were found in the lung, only CSCs were able to grow into larger metastases and had the ability to spontaneously metastasize to extrapulmonary organs such as pancreas and liver. ${ }^{38}$ Taken together, these results demonstrate the existence of a subset of cells from metastases that are tumorigenic, can differentiate, are self-renewing, and can form new metastatic lesions.

Because breast CSCs have increased metastatic properties, they should display increased motility and invasiveness, which are prerequisites for metastasis. In vivo chemotactic assays showed that invasive tumor cells from human breast tumors were significantly enriched with $\mathrm{CD} 44^{+} /$ CD24- $4^{- \text {low }}$ cells $(41 \%$ of the invading tumor cells, versus $17 \%$ of the primary tumor cells). ${ }^{37}$ In vitro studies have yielded similar results. In breast cancer cell lines expressing basal/mesenchymal markers, the $\mathrm{CD} 44^{+} / \mathrm{CD} 24^{-}$phenotype was associated with enhanced invasive properties and elevated expression of genes involved in invasion (encoding for IL-1 $\alpha$, IL-6, IL-8, CXCR4, MMP-1, and UPA). ${ }^{16}$ Similarly, $\mathrm{CD} 44^{+} / \mathrm{CD} 24^{-}$breast cancer cells that express the cell surface receptor PROCR (protein C receptor, CD201) were enriched for genes involved in cell motility, chemotaxis, and angiogenesis. ${ }^{39} \mathrm{ALDH}^{+}$cells isolated from breast cancer cell lines were more migratory and invasive than $\mathrm{ALDH}^{-}$cells. ${ }^{10,38} \mathrm{ALDH}^{+}$cells had higher expression of the IL-8 receptor CXCR $1,{ }^{10}$ which plays a role in chemotaxis. Finally, Bonuccelli et $\mathrm{a}^{40}$ recently showed that in breast cancer cells the P132L mutation of the protein caveolin-1 exhibits gain-of-function activity in migration and invasion. Caveolin-1 P132L mutation generated a specific expression signature that contains signaling pathways involved in both migration and invasion, as well as stem cell signaling and the induction of epithelial-mesenchymal transition. ${ }^{40}$

The above evidence gives strong support to the hypothesis that the metastatic population of breast cancer cells is contained within the CSCs. It remains to be determined, however, whether the CSC population can be further subdivided and whether such subsets have unique invasion/metastasis properties. Furthermore, the possibility that cancer cells other than CSCs can form metastases in vivo or in experimental models cannot be excluded. Nevertheless, non-stem cancer cells display low plating efficiency in vitro, ${ }^{16}$ have limited proliferative capacity in vivo, ${ }^{37}$ and do not produce macrometastases even when found at metastatic sites. ${ }^{38}$ This suggests that non-stem cancer cells may be not able to escape dormancy at metastatic sites and therefore may not constitute a threat to the patient's life.

\section{The Niche of Metastatic CSCs}

Tumorigenicity depends critically on the microenvironment, as well as on properties inherent to the cancer cells. CSCs require a highly specific and discrete microenvironment (the niche) that provides a physical anchoring site via adhesion molecules and supplies extrinsic factors. ${ }^{41}$ For the establishment of metastatic lesions, a permissive niche is fundamental at distant sites, just as at the primary tumor site. It has therefore been hypothesized that, when dormant 
CSCs are in the metastatic sites, their survival, proliferation, and/or differentiation can be activated by deregulated signaling from the niche. ${ }^{41-43}$ The precise mechanisms by which the metastatic niche affects CSC fate are unknown; however, two types of molecules have shown importance both in the establishment of a metastatic niche and in CSC biology: extracellular matrix (ECM) components and factors secreted by stromal cells.

\section{Signals from the ECM}

Molecules in the ECM activate specific adhesion receptors expressed on CSCs and generate signals that affect CSC fate. For example, in MCF-7 breast carcinoma cells, interaction of hyaluronic acid (HA) with CD44 causes the recruitment of Nanog into the CD44-HA complex. ${ }^{44}$ Nanog recruitment to this complex supports the activation of Nanog and the expression of pluripotent stem cell regulators such as Rex 1 and Sox $2 .{ }^{44}$ Additionally, Nanog regulates the transcriptional activity of STAT-3, promoting the expression of the ATP-binding cassette (ABC) transporter MDR $1 .{ }^{44}$ Consequently, HA-treated MCF-7 cells display a reduced intracellular retention of cytotoxic drugs and exhibit multidrug resistance. ${ }^{44}$ Both $\mathrm{HA}$ and $\mathrm{CD} 44$ are overexpressed at metastatic sites, ${ }^{45}$ suggesting that, under the influence of an HA-enriched environment, either CD44-expressing tumor cells are reprogrammed to acquire certain stem cell properties or circulating CSCs find an appropriate environment for their expansion.

CD44-HA interactions may cooperate with HER2 (ErbB2/neu) signaling to promote malignancy. The HER2 gene (ERBB2) is amplified in $20 \%$ to $30 \%$ of human breast cancers and is associated with the metastatic phenotype. ${ }^{46}$ The role of HER2 amplification in CSC expansion is supported by multiple lines of evidence: i) HER2 overexpression correlated with the expression of the stem cell marker ALDH in breast cancer patients, ${ }^{9}$ ii) increased HER2 transgene expression in mice increased self-renewal and replicative potential of CSCs, ${ }^{47}$ and iii) HER2 overexpression in breast cancer cell lines increased the CSC population, as demonstrated by increased ALDH activity, mammosphere formation, tumorigenesis, and expression of stem cell related genes. ${ }^{48}$ ErbB2-induced mammary tumor progression and breast cancer stem cell expansion is at least in part mediated via the canonical NF- $\kappa$ B pathway. ${ }^{49}$ In addition, CD44 and HER2 can be physically linked via interchain disulfide bonds in ovarian cancer cells. ${ }^{50}$ The crosstalk between these receptors was corroborated by assays in which HA binding to CD44 activated the tyrosine kinase activity of HER2. ${ }^{50}$ The HER2 agonist heregulin promotes HA synthesis and the consequent downstream activation of CD $44 .{ }^{51}$ CD 44 -mediated signaling may contribute significantly both to the cytoskeletal regulation needed for invasion ${ }^{52}$ and to CSC expansion. ${ }^{44}$

Integrin family members modulate the survival and proliferation of CSCs. The expression of the $\alpha 6$ integrin subunit (CD49f) increases with serial passages of mammospheres generated from individual MCF-7 cells. ${ }^{53}$ This phenotype correlates with the enrichment of a subpopu- lation with stem cell characteristics (ie, a lineage ${ }^{-}$phenotype and enriched long-term culture-initiating cells) that displays increased proliferation and greater resistance to drug-induced apoptosis. ${ }^{53}$ Of note, inhibition of $\alpha 6$ integrin by antibodies or small interfering RNA (siRNA) induces the complete loss of mammosphere-forming ability and inhibits tumorigenicity. ${ }^{53}$ The expression of $\alpha 6$ integrin correlates with reduced survival in breast cancer patients and increased metastatic potential and survival of breast carcinoma cells. Together, these data indicate that $\alpha 6$ integrin is necessary for survival and/or proliferation of CSCs and suggest that ligands of $\alpha 6$ integrin may be important for the growth of metastatic tumors in a manner similar to the fate of CD44.

\section{Signals from Stromal Cells}

In addition to ECM components, the different types of cells in the metastatic niche include fibroblasts, infiltrating cells from the immune system, and endothelial cells. ${ }^{54}$ All of these cells are able to secrete factors that promote metastasis. For example, the chemokine CXCL12 is expressed by stromal fibroblasts and endothelial cells and, through the activation of its receptor CXCR4, has a prominent role in the homing of tumor cells to particular organs. CXCR4 is commonly overexpressed in human breast cancers, and its expression level correlates with tumor aggressiveness and presence of lung metastasis in mouse models. ${ }^{55}$ Accordingly, treatment of breast cancer cells with CXCR4-neutralizing antibodies or down-regulation of the receptor by siRNA reduced experimental lung metastasis. ${ }^{56,57}$ CXCR4 expression has also been associated with the detection of disseminated tumor cells in bone marrow in breast cancer patients. ${ }^{58}$ Even though it is not clear whether these cells are tumorigenic, the majority are $\mathrm{CD} 44^{+} / \mathrm{CD} 24^{-},{ }^{28}$ suggesting that CSCs are sensitive to chemokine-induced homing.

In addition to differentiated stromal cells, pluripotent cells also can provide signals that promote metastasis. Hematopoietic progenitor cells express the CXCR4 receptor and are thereby attracted to the metastatic site by CXCL12. ${ }^{59}$ However, hematopoietic progenitor cells are present in expected metastatic sites (eg, axillary lymph nodes) without any evidence of micrometastasis, ${ }^{59}$ suggesting that these cells participate in the creation of a receptive microenvironment (a pre-metastatic niche).

Mesenchymal stem cells (MSCs) may also increase metastatic potential by producing signals at both primary and metastatic sites. MSCs accumulate in the tumor and lung on intravenous injection in osteosarcoma-bearing mice. ${ }^{60}$ MSCs increase the rate of osteosarcoma lung metastasis via secretion of CCL5. ${ }^{60}$ Human MSCs also stimulate breast cancer cell migration, invasion, and metastasis through the secretion of CXCL12, ${ }^{61} \mathrm{IL}-6,{ }^{62}$ and CCL5. ${ }^{63}$ The secretion of CCL5 from MSCs is dependent on the presence of cancer cells ${ }^{63}$ or their conditioned medium, ${ }^{64}$ indicating that the interaction between cancer cells and their niche is reciprocal. 


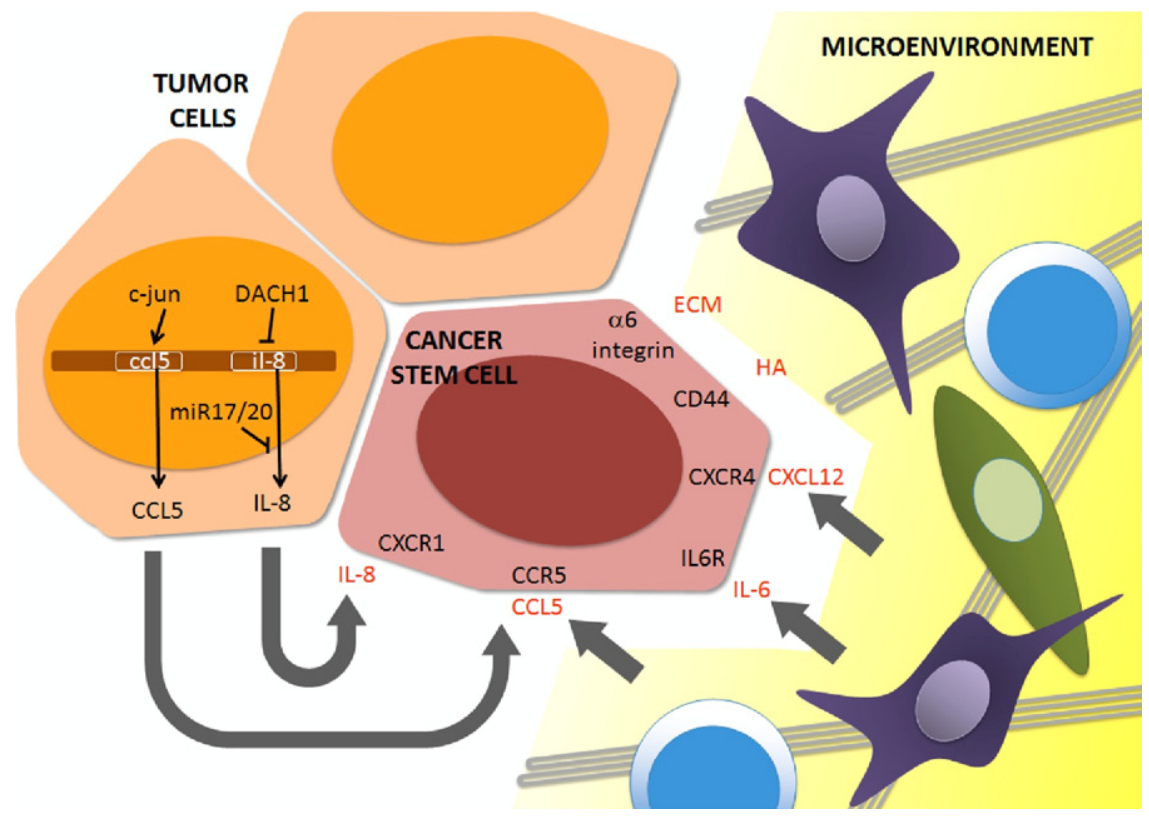

Figure 1. Signals that contribute to invasiveness and homing in breast cancer stem cells. Tumor cells secrete IL- 8 because DACH1 and miR-17/20, negative regulators of IL- 8 expression, are commonly lost in breast cancer cells. CCL5 can also be secreted by tumor cells, in which it is under the transcriptional control of the oncogene JUN (c-Jun) or by of nonmalignant stromal cells. In addition, stromal cells can produce IL-6 and CXCL12. Other signals from the microenvironment include hyaluronic acid (HA) and other extracellular matrix (ECM) components. Through the activation of their corresponding receptors, all of these signals cooperate to induce a metastatic phenotype in breast CSCs.

\section{Signals That Promote the Metastatic CSC Phenotype}

The cellular programs and the specific mechanisms by which cancer cells affect their primary and metastatic niches sites are currently under investigation. Recent evidence indicates that these pathways regulate both invasiveness and CSC features (Figure 1). The pathways discussed below constitute novel examples of these programs and could therefore become targets for development of antimetastatic therapies.

\section{The Proto-Oncogene JUN}

A major component of the activator protein 1 (AP-1) transcription factor is encoded by the JUN proto-oncogene (alias c-Jun), which regulates diverse biological functions. JUN induces cyclin D1 expression ${ }^{65}$ and JUN overexpression correlates with breast cancer tumorigenesis and metastasis. ${ }^{66}$ Forced JUN overexpression in MCF-7 breast cancer cells increased tumor formation in nude mice and cell motility and invasiveness in vitro. ${ }^{67}$ Recent studies provided evidence for a link between breast CSCs and cellular invasion. Using bitransgenic mice encoding a floxed JUN allele and mammary targeted ErbB2, investigators examined the biological importance of endogenous JUN in breast tumor progression. In $\mathrm{ErbB}^{+}$mammary tumor cells, JUN controlled the transcriptional expression of stem cell factor (SCF) and CCL5. ${ }^{68}$ Reduction in SCF decreased the proportion of cells expressing breast CSC markers and CSC self-renewal. JUN-mediated expression of CCL5 played an essential role in the autocrine control of the migration and invasion of breast cancer cells. ${ }^{68}$ These studies demonstrated that a single cellular oncogene is necessary both to activate the signaling pathways that promote features of CSCs and to maintain the invasive phenotype of mammary tumors.

\section{The Cell Fate Determination Factor DACH1}

DACH1 is the human homolog of the Drosophila melanogaster dachshund gene (dac). In Drosophila, dac is a key member of the retinal determination gene network required for eye and leg development; dac is expressed in progenitor cells and neurons of mushroom bodies, the insect brain structures that are required for fly learning and memory. ${ }^{69}$ In mammals, $\mathrm{DACH} 1$ has been implicated in breast, prostate, ovarian, and endometrial tumorigenesis. ${ }^{70-72}$ The function of endogenous DACH1 to inhibit tumorigenesis may be mediated by its ability to directly bind DNA in the context of local chromatin and to compete with oncogenic transcription factors for the regulation of gene transcription. ${ }^{73} \mathrm{DACH} 1$ is lost in poorprognosis invasive breast cancer. ${ }^{70,74}$ Recent studies demonstrated that endogenous $\mathrm{DACH} 1$ controls stem cell gene expression. ${ }^{75}$ Induction of $\mathrm{DACH} 1$ expression in vivo reduced the proportion of $\mathrm{CD} 24^{-/ \text {low }}$ cells in mammary tumors by $\sim 50 \%$. DACH1 expression decreased the number of mammospheres by $\sim 60 \%$, and the relative proportion of CD44 ${ }^{\text {high }} / \mathrm{CD} 24^{\text {low }}$ cells in vitro. Conversely, short hairpin RNA (shRNA) to DACH1 enhanced mammosphere formation. DACH1 repressed the expression of Sox2 and Nanog by directly binding their promoters. ${ }^{75}$ Earlier, it was shown that DACH1 inhibits cellular migration, invasion, and metastatic capability of breast cancer cells by binding and repressing the IL-8 gene. ${ }^{76}$ Thus, $\mathrm{DACH} 1$ is an example of an endogenous cell-fate determination factor that controls the expression of key genes that affect breast cancer cell stemness and alter the heterotypic signaling required for metastasis.

\section{$N F-\kappa B$}

The NF- $\kappa$ B family of transcription factors includes c-Rel, RelB, RelA (p65), NF- $\mathrm{B} 1$, and NF- $\mathrm{B}^{\mathrm{B} 2}$. These proteins regulate a wide variety of genes involved in the response 
to inflammatory cytokine signaling, infectious agents, and DNA damage. ${ }^{77}$ The canonical pathway of regulation of NF- $\kappa \mathrm{B}$ involves activation of $I_{\kappa} \mathrm{B}$ kinase (IKK) complex. Active IKK phosphorylate $I_{\kappa} \mathrm{B} \alpha$, resulting in its ubiquitination and proteasome-mediated degradation, with subsequent release of $\mathrm{NF}-\kappa \mathrm{B}$ dimers for nuclear translocation. ${ }^{78} \mathrm{NF}-\kappa \mathrm{B}$ family members are overexpressed or activated in breast cancer cell lines and primary human breast tumors. $^{79}$ Inhibition of NF- $\kappa$ B pathway through the expression of a stabilized form of the $\left.\right|_{\kappa} \mathrm{B} \alpha \quad\left(\mathrm{I}_{\kappa} \mathrm{B} \alpha \mathrm{SR}\right)$ blocked the growth and caused regression of human mammary tumor cell xenografts in mice. ${ }^{80} \mathrm{NF}-\kappa \mathrm{B}$ activity enhanced ErbB2-mediated mammary tumorigenesis in vivo by promoting growth and survival signaling via the heterotypic secretion of vascular endothelial growth factor (VEGF) and the induction of tumor vasculogenesis. ${ }^{81}$ The tumorigenic function of NF- $\kappa \mathrm{B}$ in the normally developed adult mammary gland of immunocompetent mice was recently analyzed. ${ }^{49}$ In vivo inducible expression of $I_{\kappa} \mathrm{B} \alpha \mathrm{SR}$ in the adult mammary epithelium delayed the onset and number of new tumors. Tumor infiltration of macrophages, tumor neoangiogenesis, and the expression of VEGF and several other secreted factors (Acrp30, Mip2, CCL5, K6, MMP-3, and MMP-9) were reduced on induction of the $l_{\kappa} B \alpha S R$ transgene. ${ }^{49}$ Suppression of NF- $\kappa \mathrm{B}$ activation reduced the $\mathrm{CD} 44^{+} / \mathrm{CD} 24^{-}$population in transgenic tumors, reduced stem cell expansion in vitro, and repressed expression of Nanog and Sox2 in vivo and in vitro. ${ }^{49}$

The NF- $\kappa$ B pathway promotes invasion by breast cancer cells by inducing the expression of secreted factors and enzymes. NF- $\kappa \mathrm{B}$ and AP-1 controlled the expression of urokinase-type plasminogen activator (UPA) and its receptor (UPAR), and expression of both UPA and UPAR correlated with invasive cancer cell phenotype and poor prognosis. ${ }^{82}$ The inhibition of NF- $\kappa \mathrm{B}$ and $\mathrm{AP}-1$ suppressed the secretion of UPA, resulting in the inhibition of motility of highly invasive breast cancer cells. ${ }^{82}$ Furthermore, the NF- $\kappa$ B pathway, but not the Raf pathway, stimulates the invasion of breast cancer cells by controlling the expression of the proteases MMP-1 and MMP- $2 .{ }^{83}$

\section{MicroRNAs}

MicroRNAs (miRNAs) are small noncoding RNAs that regulate the translation and stability of mRNAs, and miRNAs are important for the coordination of cell growth, cell cycle control, and self-renewal in both normal stem cells and CSCs. ${ }^{84}$ Recently, several miRNAs known to contribute to the CSC phenotype have been associated with the development of metastasis (reviewed by Valastyan and Weinberg ${ }^{85}$ and Shi et al ${ }^{86}$ ).

The miR-17/20 cluster, which has been shown to regulate breast cancer cell growth, ${ }^{87}$ was recently noted to have potential to govern cellular migration and invasion. Comparison of miRNAs in human mammary primary tumors with lymph node-positive versus lymph node-negative status identified the miR-17/20 cluster as inversely correlated with the presence of lymph node metastasis. ${ }^{88}$ Expression of miR-17 and miR-20 was increased in noninvasive breast cancer cell lines, compared with highly invasive cell lines. ${ }^{88}$ Furthermore, the miR-17/20 cluster repressed the expression and secretion of promigratory chemokines (CXCL1, IL-8, and IL-10), plasminogen activators (cytokeratin- 8 and $\alpha$-enolase), and fibronectin in breast cancer cell lines. ${ }^{88}$ Accordingly, conditioned medium from miR-17/20-overexpressing MCF-7 breast cancer cells was able to inhibit migration and invasion of MDA-MB-231 cells. ${ }^{88}$ The authors also showed that alterations in the cancer cell microenvironment from reduction of the abundance of specific secreted proteins produce an antimetastatic phenotype and that this phenotype can be transmitted to other cell types. ${ }^{88}$

The miR-17/20 cluster is also important in the regulation of pluripotentiality; miR-17/20 targets cell cycle regulators, including the cyclin D1 gene via its $3^{\prime} \cup T R{ }^{87}$ The importance of cyclin D1 in normal and cancer stem cell biology was recently reviewed. ${ }^{84}$ Important new findings link cyclin D1 to stem cell function via Notch. Cyclin D1 expression during development was shown to correlate with the expression of Notch, and cyclin D1 was required for Notch1-mediated transformation and contact-independent growth. ${ }^{89}$ Subsequent studies in breast cancer cells demonstrated that cyclin D1 enhances Notch1 activity by inhibiting the expression of its negative regulator, Numb. ${ }^{90}$ Consistent with these findings, cyclin D1 knockout mice showed resistance to Notch1-induced mammary tumorigenesis. ${ }^{91}$ In addition, cyclin D1 promotes cellular migration by different mechanisms. ${ }^{92}$ The regulatory loop that exists between miR-17/20 and cyclin D1 may therefore be important both in the acquisition of metastatic potential and in the stem cell phenotype.

Other miRNAs involved in metastasis of breast cancer promote epithelial-mesenchymal transition (characterized by the loss of E-cadherin and increase in vimentin and $\mathrm{N}$-cadherin), rather than altering the microenvironment. The miR-141, miR-200a, miR-200b, miR-200c, and miR-429 molecules (all of which are members of the miRNA-200 family) promote epithelial differentiation by inhibiting mRNA translation of ZEB1 and ZEB2, two activators of epithelial-mesenchymal transition. ${ }^{93,94}$ ZEB1 in turn suppresses the expression of the miR-200 family members miR-183 and miR-203. ${ }^{95,96}$ The shRNA-mediated inhibition of ZEB1 allowed miR-183 and miR-203 to suppress the expression of the stem cell factors Bmi1, Sox2, and KLF4, the tumorsphere-forming capacity, the tumorigenicity, and the metastatic ability of pancreatic cancer cells. ${ }^{96}$ It has been proposed that ZEB1 and its activity as a repressor of miRNAs expression are necessary not only to drive epithelial-mesenchymal transition, but also to maintain a stemness phenotype and, consequently, a metastasis-initiating capacity. ${ }^{96}$

\section{How To Eradicate CSC-Driven Metastases?}

An efficient cure for metastatic cancer will involve either the eradication of the subset of cancer cells that have the potential to metastasize or the blockage of their establishment/growth at metastatic sites. For example, depletion of the CSC pool reduced the metastatic phenotype of pancreatic tumors. ${ }^{97}$ Different strategies may be applica- 
ble in the eradication of breast CSCs. First, once the precise phenotype of the metastatic breast CSCs has been determined, targeting specific phenotypic markers may be useful. This approach was partially successful in acute myeloid leukemia. ${ }^{98}$ Second, modulation of ABC transporters can help to overcome drug resistance in CSCs. ${ }^{30}$ Unfortunately, clinical trials with compounds that block $A B C$ transporters have revealed serious side effects. ${ }^{99}$ The ionophore salinomycin, however, which induces a conformational change of the $A B C$ transporter MDR1/ABCB1 that reduces its activity, ${ }^{100}$ has been identified as toxic to breast CSCs by high-throughput screening. ${ }^{101}$ Of note, salinomycin has also been shown to reduce experimental metastases in breast cancer models. ${ }^{101}$ Third, the molecules that participate in self-renewal and cell fate are also potential targets in breast CSC therapy. The therapeutic potential of HER2, Notch, Wnt, and Hedgehog pathways is currently being investigated (reviewed by Kakarala and Wicha ${ }^{18}$ ). Inhibition of Hedgehog signaling in xenografts established from pancreatic cancer cell lines reduced the number of ALDH-overexpressing cancer cells. ${ }^{102}$ In that same study, inhibition of Hedgehog signaling blocked systemic metastases, but had minimal effect on primary tumor volume. ${ }^{102}$ Finally, CSC-specific miRNAs can be targeted by using antisense miRNA. Blocking the prometastatic miR-10b with a chemically modified antisense oligonucleotide markedly suppressed pulmonary metastases in murine breast cancer models. ${ }^{103}$

Interruption of signals generated in the CSC niche may be also useful in blocking metastasis formation and/or improving therapeutic responses. ${ }^{84}$ Blocking cell adhesion receptors such as CD44 or $\alpha 6$ integrin with antibodies or soluble ligands disrupts CSC-matrix interactions. ${ }^{104} \mathrm{~A}$ monoclonal antibody against CD44 induced terminal differentiation and apoptosis of AML cells in engrafted mice. ${ }^{105}$ Inhibition of CXCR4 with antibodies or an 18-amino-acid specific inhibitor reduced experimental metastasis to lung in breast cancer models, ${ }^{56}$ suggesting that CXCR-4 inhibitors are effective in blocking cancer cell homing. Administration of anti-CCL5 neutralizing antibody blocked the enhanced metastatic capability of breast cancer cells caused by coinjection with MSCs. ${ }^{63}$ Similarly, a neutralizing antibody against IL-8 blocked breast tumor metastasis. ${ }^{76}$ Repertaxin, an inhibitor of the IL-8 receptor CXCR1, reduced the breast CSC population and led to apoptosis in the tumor population and decreased metastasis. ${ }^{106}$ These promising data indicate that targeting the paracrine/autocrine signals in the microenvironment may reduce the survival and metastatic capability of CSCs.

\section{Conclusions}

Cancer stem cells have a central role in breast cancer progression because they are involved in tumorigenesis and resistance to therapeutic regimens. Several clinical studies have found a correlation between the increase in CSC number and the presence of metastasis. Evidence from in vivo models of metastasis and from in vitro assays shows that CSCs exhibit increased invasiveness and metastatic ability, indicating that breast CSCs also play a key role in the formation of secondary tumors.

The microenvironment is a critical regulator of CSCdriven metastasis. Signals from the ECM or stromal cells can act as chemoattractants or may regulate dormancy at metastatic sites. Furthermore, specific cellular programs allow cancer cells to modify their microenvironment through the secretion of autocrine/paracrine signals that increase invasiveness. Because some of these programs also promote CSC features, they may constitute the molecular basis of the stemness-metastasis link. All of these signals provide potential targets for the modulation of CSC fate, the response to therapeutic agents, and the eradication of metastatic CSCs. Novel approaches that target the breast CSC microenvironment may thus become the basis for generation of effective and clinically applicable therapies that prevent disease relapse and metastasis and enhance patient survival.

\section{Acknowledgments}

We thank Aliesha Gonzalez (Universidad Nacional Autónoma de México, Mexico City), Marisol de la Fuente (Instituto Politécnico Nacional), and Steven McMahon (Thomas Jefferson University, Philadelphia, PA) for critical reading of the manuscript.

\section{References}

1. Al-Hajj M, Wicha MS, Benito-Hernandez A, Morrison SJ, Clarke MF: Prospective identification of tumorigenic breast cancer cells [Erratum appeared in Proc Natl Acad Sci USA 2003, 100:6890]. Proc Natl Acad Sci USA 2003, 100:3983-3988

2. Ponti D, Costa A, Zaffaroni N, Pratesi G, Petrangolini G, Coradini D, Pilotti S, Pierotti MA, Daidone MG: Isolation and in vitro propagation of tumorigenic breast cancer cells with stem/progenitor cell properties. Cancer Res 2005, 65:5506-5511

3. Fillmore CM, Kuperwasser C: Human breast cancer cell lines contain stem-like cells that self-renew, give rise to phenotypically diverse progeny and survive chemotherapy. Breast Cancer Res 2008, 10:R25

4. Wright MH, Calcagno AM, Salcido CD, Carlson MD, Ambudkar SV, Varticovski L: Brca1 breast tumors contain distinct CD44+/CD24and CD133+ cells with cancer stem cell characteristics. Breast Cancer Res 2008, 10:R10

5. Dontu G, Abdallah WM, Foley JM, Jackson KW, Clarke MF, Kawamura MJ, Wicha MS: In vitro propagation and transcriptional profiling of human mammary stem/progenitor cells. Genes Dev 2003, 17: 1253-1270

6. Dontu G, Jackson KW, McNicholas E, Kawamura MJ, Abdallah WM, Wicha MS: Role of Notch signaling in cell-fate determination of human mammary stem/progenitor cells. Breast Cancer Res 2004, 6:R605-R615

7. Corti S, Locatelli F, Papadimitriou D, Donadoni C, Salani S, Del Bo R, Strazzer S, Bresolin N, Comi GP: Identification of a primitive brainderived neural stem cell population based on aldehyde dehydrogenase activity. Stem Cells 2006, 24:975-985

8. Hess DA, Meyerrose TE, Wirthlin L, Craft TP, Herrbrich PE, Creer $\mathrm{MH}$, Nolta JA: Functional characterization of highly purified human hematopoietic repopulating cells isolated according to aldehyde dehydrogenase activity. Blood 2004, 104:1648-1655

9. Ginestier C, Hur MH, Charafe-Jauffret E, Monville F, Dutcher J, Brown M, Jacquemier J, Viens P, Kleer CG, Liu S, Schott A, Hayes D, Birnbaum D, Wicha MS, Dontu G: ALDH1 is a marker of normal and malignant human mammary stem cells and a predictor of poor clinical outcome. Cell Stem Cell 2007, 1:555-567 
10. Charafe-Jauffret E, Ginestier C, lovino F, Wicinski J, Cervera N, Finetti P, Hur MH, Diebel ME, Monville F, Dutcher J, Brown M, Viens P, Xerri L, Bertucci F, Stassi G, Dontu G, Birnbaum D, Wicha MS: Breast cancer cell lines contain functional cancer stem cells with metastatic capacity and a distinct molecular signature. Cancer Res 2009, 69:1302-1313

11. Charafe-Jauffret E, Ginestier C, Iovino F, Tarpin C, Diebel M, Esterni B, Houvenaeghel G, Extra JM, Bertucci F, Jacquemier J, Xerri L, Dontu G, Stassi G, Xiao Y, Barsky SH, Birnbaum D, Viens P, Wicha MS: Aldehyde dehydrogenase 1-positive cancer stem cells mediate metastasis and poor clinical outcome in inflammatory breast cancer. Clin Cancer Res 2010, 16:45-55

12. Liu JC, Deng T, Lehal RS, Kim J, Zacksenhaus E: Identification of tumorsphere- and tumor-initiating cells in HER2/Neu-induced mammary tumors. Cancer Res 2007, 67:8671-8681

13. Cho RW, Wang X, Diehn M, Shedden K, Chen GY, Sherlock G, Gurney A, Lewicki J, Clarke MF: Isolation and molecular characterization of cancer stem cells in MMTV-Wnt-1 murine breast tumors. Stem Cells 2008, 26:364-371

14. Vassilopoulos A, Wang RH, Petrovas C, Ambrozak D, Koup R, Deng $\mathrm{CX}$ : Identification and characterization of cancer initiating cells from BRCA1 related mammary tumors using markers for normal mammary stem cells. Int J Biol Sci 2008, 4:133-142

15. Kim RJ, Kim SR, Roh KJ, Park SB, Park JR, Kang KS, Kong G, Tang B, Yang YA, Kohn EA, Wakefield LM, Nam JS: Ras activation contributes to the maintenance and expansion of Sca-1pos cells in a mouse model of breast cancer. Cancer Lett 2010, 287:172-181

16. Sheridan C, Kishimoto H, Fuchs RK, Mehrotra S, Bhat-Nakshatri P, Turner CH, Goulet R Jr, Badve S, Nakshatri H: CD44+/CD24breast cancer cells exhibit enhanced invasive properties: an early step necessary for metastasis. Breast Cancer Res 2006, 8:R59

17. Prestegarden L, Enger $P \varnothing$ : Cancer stem cells in the central nervous system-a critical review. Cancer Res 2010, 70:8255-8258

18. Kakarala M, Wicha MS: Implications of the cancer stem-cell hypothesis for breast cancer prevention and therapy. J Clin Oncol 2008, 26:2813-2820

19. Liu S, Wicha MS: Targeting breast cancer stem cells. J Clin Oncol 2010, 28:4006-4012

20. Wicha MS: Cancer stem cells and metastasis: lethal seeds. Clin Cancer Res 2006, 12:5606-5607

21. Li F, Tiede B, Massagué J, Kang Y: Beyond tumorigenesis: cancer stem cells in metastasis. Cell Res 2007, 17:3-14

22. Allan AL, Vantyghem SA, Tuck AB, Chambers AF: Tumor dormancy and cancer stem cells: implications for the biology and treatment of breast cancer metastasis. Breast Dis 2006, 26:87-98

23. Weiss L: Metastatic inefficiency. Adv Cancer Res 1990, 54:159-211

24. Minn AJ, Kang Y, Serganova I, Gupta GP, Giri DD, Doubrovin M, Ponomarev V, Gerald WL, Blasberg R, Massagué J: Distinct organspecific metastatic potential of individual breast cancer cells and primary tumors. J Clin Invest 2005, 115:44-55

25. Abraham BK, Fritz P, McClellan M, Hauptvogel P, Athelogou M, Brauch H: Prevalence of CD44+/CD24-/low cells in breast cancer may not be associated with clinical outcome but may favor distant metastasis. Clin Cancer Res 2005, 11:1154-1159

26. Aktas B, Tewes M, Fehm T, Hauch S, Kimmig R, Kasimir-Bauer S: Stem cell and epithelial-mesenchymal transition markers are frequently overexpressed in circulating tumor cells of metastatic breast cancer patients. Breast Cancer Res 2009, 11:R46

27. Theodoropoulos PA, Polioudaki H, Agelaki S, Kallergi G, Saridaki Z, Mavroudis D, Georgoulias V: Circulating tumor cells with a putative stem cell phenotype in peripheral blood of patients with breast cancer. Cancer Lett 2010, 288:99-106

28. Balic M, Lin H, Young L, Hawes D, Giuliano A, McNamara G, Datar $\mathrm{RH}$, Cote RJ: Most early disseminated cancer cells detected in bone marrow of breast cancer patients have a putative breast cancer stem cell phenotype. Clin Cancer Res 2006, 12:5615-5621

29. Yu F, Yao H, Zhu P, Zhang X, Pan Q, Gong C, Huang Y, Hu X, Su F, Lieberman J, Song E: let-7 regulates self renewal and tumorigenicity of breast cancer cells. Cell 2007, 131:1109-1123

30. Dean M: ABC transporters, drug resistance, and cancer stem cells. J Mammary Gland Biol Neoplasia 2009, 14:3-9

31. Lacerda L, Pusztai L, Woodward WA: The role of tumor initiating cells in drug resistance of breast cancer: implications for future therapeutic approaches. Drug Resist Updat 2010, 13:99-108
32. Liu R, Wang X, Chen GY, Dalerba P, Gurney A, Hoey T, Sherlock G Lewicki J, Shedden K, Clarke MF: The prognostic role of a gene signature from tumorigenic breast-cancer cells. N Engl J Med 2007 356:217-226

33. Neumeister V, Agarwal S, Bordeaux J, Camp RL, Rimm DL: In situ identification of putative cancer stem cells by multiplexing ALDH1, CD44, and cytokeratin identifies breast cancer patients with poor prognosis. Am J Pathol 2010, 176:2131-2138

34. Resetkova E, Reis-Filho JS, Jain RK, Mehta R, Thorat MA, Nakshatri $\mathrm{H}$, Badve S: Prognostic impact of ALDH1 in breast cancer: a story of stem cells and tumor microenvironment. Breast Cancer Res Treat 2010, 123:97-108

35. Marcato P, Dean CA, Pan D, Araslanova R, Gillis M, Joshi M, Helyer L, Pan L, Leidal A, Gujar S, Giacomantonio CA, Lee PW: Aldehyde dehydrogenase activity of breast cancer stem cells is primarily due to isoform ALDH1A3 and its expression is predictive of metastasis. Stem Cells 2011, 29:32-45

36. Kang Y, Siegel PM, Shu W, Drobnjak M, Kakonen SM, Cordón-Cardo C, Guise TA, Massagué J: A multigenic program mediating breast cancer metastasis to bone. Cancer Cell 2003, 3:537-549

37. Liu H, Patel MR, Prescher JA, Patsialou A, Qian D, Lin J, Wen S Chang YF, Bachmann MH, Shimono Y, Dalerba P, Adorno M, Lobo N, Bueno J, Dirbas FM, Goswami S, Somlo G, Condeelis J, Contag $\mathrm{CH}$, Gambhir SS, Clarke MF: Cancer stem cells from human breast tumors are involved in spontaneous metastases in orthotopic mouse models. Proc Natl Acad Sci USA 2010, 107:18115-18120

38. Croker AK, Goodale D, Chu J, Postenka C, Hedley BD, Hess DA Allan AL: High aldehyde dehydrogenase and expression of cance stem cell markers selects for breast cancer cells with enhanced malignant and metastatic ability. J Cell Mol Med 2009, 13:22362252

39. Shipitsin M, Campbell LL, Argani P, Weremowicz S, BloushtainQimron N, Yao J, Nikolskaya T, Serebryiskaya T, Beroukhim R, Hu M, Halushka MK, Sukumar S, Parker LM, Anderson KS, Harris LN Garber JE, Richardson AL, Schnitt SJ, Nikolsky Y, Gelman RS, Polyak K: Molecular definition of breast tumor heterogeneity. Cancer Cell 2007, 11:259-273

40. Bonuccelli G, Casimiro MC, Sotgia F, Wang C, Liu M, Katiyar S, Zhou J, Dew E, Capozza F, Daumer KM, Minetti C, Milliman JN, Alpy F, Rio MC, Tomasetto C, Mercier I, Flomenberg N, Frank PG, Pestell RG Lisanti MP: Caveolin-1 (P132L), a common breast cancer mutation, confers mammary cell invasiveness and defines a novel stem cell/ metastasis-associated gene signature. Am J Pathol 2009, 174: 1650-1662

41. Li L, Neaves WB: Normal stem cells and cancer stem cells: the niche matters [Erratum appeared in Cancer Res 2006;66:6458]. Cancer Res 2006, 66:4553-4557

42. Wicha MS, Liu S, Dontu G: Cancer stem cells: an old idea-a paradigm shift. Cancer Res 2006, 66:1883-1890; discussion 1895-1886

43. Borovski T, De Sousa E Melo F, Vermeulen L, Medema JP: Cance stem cell niche: the place to be. Cancer Res 2011, 71:634-639

44. Bourguignon LY, Peyrollier K, Xia W, Gilad E: Hyaluronan-CD44 interaction activates stem cell marker Nanog, Stat-3-mediated MDR1 gene expression, and ankyrin-regulated multidrug efflux in breast and ovarian tumor cells. J Biol Chem 2008, 283:17635-17651

45. Auvinen P, Tammi R, Tammi M, Johansson R, Kosma VM: Expression of CD $44 \mathrm{~s}, \mathrm{CD} 44 \vee 3$ and CD $44 \vee 6$ in benign and malignant breast lesions: correlation and colocalization with hyaluronan. Histopathology 2005, 47:420-428

46. Slamon DJ, Clark GM, Wong SG, Levin WJ, Ullrich A, McGuire WL: Human breast cancer: correlation of relapse and survival with amplification of the HER-2/neu oncogene. Science 1987, 235:177-182

47. Cicalese A, Bonizzi G, Pasi CE, Faretta M, Ronzoni S, Giulini B, Brisken C, Minucci S, Di Fiore PP, Pelicci PG: The tumor suppressor p53 regulates polarity of self-renewing divisions in mammary stem cells. Cell 2009, 138:1083-1095

48. Korkaya $H$, Paulson A, lovino F, Wicha MS: HER2 regulates the mammary stem/progenitor cell population driving tumorigenesis and invasion. Oncogene 2008, 27:6120-6130

49. Liu M, Sakamaki T, Casimiro MC, Willmarth NE, Quong AA, Ju X, Ojeifo J, Jiao X, Yeow WS, Katiyar S, Shirley LA, Joyce D, Lisanti MP, Albanese C, Pestell RG: The canonical NF-kappaB pathway governs mammary tumorigenesis in transgenic mice and tumor stem cell expansion. Cancer Res 2010, 70:10464-10473 
50. Bourguignon LY, Zhu H, Chu A, lida N, Zhang L, Hung MC: Interaction between the adhesion receptor, CD44, and the oncogene product, p185HER2, promotes human ovarian tumor cell activation. J Biol Chem 1997, 272:27913-27918

51. Bourguignon LY, Gilad E, Peyrollier K: Heregulin-mediated ErbB2ERK signaling activates hyaluronan synthases leading to CD44dependent ovarian tumor cell growth and migration. J Biol Chem 2007, 282:19426-19441

52. Bourguignon LY: Hyaluronan-mediated CD44 activation of RhoGTPase signaling and cytoskeleton function promotes tumor progression. Semin Cancer Biol 2008, 18:251-259

53. Cariati M, Naderi A, Brown JP, Smalley MJ, Pinder SE, Caldas C, Purushotham AD: Alpha-6 integrin is necessary for the tumourigenicity of a stem cell-like subpopulation within the MCF7 breast cancer cell line. Int J Cancer 2008, 122:298-304

54. Wels J, Kaplan RN, Rafii S, Lyden D: Migratory neighbors and distant invaders: tumor-associated niche cells. Genes Dev 2008, 22:559-574

55. Dewan MZ, Ahmed S, Iwasaki Y, Ohba K, Toi M, Yamamoto N: Stromal cell-derived factor-1 and CXCR4 receptor interaction in tumor growth and metastasis of breast cancer. Biomed Pharmacother 2006, 60:273-276

56. Muller A, Homey B, Soto H, Ge N, Catron D, Buchanan ME, McClanahan T, Murphy E, Yuan W, Wagner SN, Barrera JL, Mohar A, Verástegui E, Zlotnik A: Involvement of chemokine receptors in breast cancer metastasis. Nature 2001, 410:50-56

57. Smith MC, Luker KE, Garbow JR, Prior JL, Jackson E, PiwnicaWorms D, Luker GD: CXCR4 regulates growth of both primary and metastatic breast cancer. Cancer Res 2004, 64:8604-8612

58. Andre F, Cabioglu N, Assi H, Sabourin JC, Delaloge S, Sahin A, Broglio K, Spano JP, Combadiere C, Bucana C, Soria JC, Cristofanilli $\mathrm{M}$ : Expression of chemokine receptors predicts the site of metastatic relapse in patients with axillary node positive primary breast cancer. Ann Oncol 2006, 17:945-951

59. Psaila B, Kaplan RN, Port ER, Lyden D: Priming the 'soil' for breast cancer metastasis: the pre-metastatic niche. Breast Dis 2006, 26 : 65-74

60. Xu WT, Bian ZY, Fan QM, Li G, Tang TT: Human mesenchymal stem cells (hMSCs) target osteosarcoma and promote its growth and pulmonary metastasis. Cancer Lett 2009, 281:32-41

61. Corcoran KE, Trzaska KA, Fernandes H, Bryan M, Taborga M, Srinivas V, Packman K, Patel PS, Rameshwar P: Mesenchymal stem cells in early entry of breast cancer into bone marrow. PLoS One 2008, 3:e2563

62. Sasser AK, Sullivan NJ, Studebaker AW, Hendey LF, Axel AE, Hall BM: Interleukin-6 is a potent growth factor for ER-alpha-positive human breast cancer. FASEB J 2007, 21:3763-3770

63. Karnoub AE, Dash AB, Vo AP, Sullivan A, Brooks MW, Bell GW, Richardson AL, Polyak K, Tubo R, Weinberg RA: Mesenchymal stem cells within tumour stroma promote breast cancer metastasis. Nature 2007, 449:557-563

64. Pinilla S, Alt E, Abdul Khalek FJ, Jotzu C, Muehlberg F, Beckmann C, Song YH: Tissue resident stem cells produce CCL5 under the influence of cancer cells and thereby promote breast cancer cell invasion. Cancer Lett 2009, 284:80-85

65. Albanese C, Johnson J, Watanabe G, Eklund N, Vu D, Arnold A Pestell RG: Transforming p21ras mutants and c-Ets-2 activate the cyclin D1 promoter through distinguishable regions. J Biol Chem 1995, 270:23589-23597

66. Gee JM, Barroso AF, Ellis IO, Robertson JF, Nicholson RI: Biological and clinical associations of c-jun activation in human breast cancer. Int J Cancer 2000, 89:177-186

67. Smith LM, Wise SC, Hendricks DT, Sabichi AL, Bos T, Reddy P, Brown PH, Birrer MJ: cJun overexpression in MCF-7 breast cancer cells produces a tumorigenic, invasive and hormone resistant phenotype. Oncogene 1999, 18:6063-6070

68. Jiao X, Katiyar S, Willmarth NE, Liu M, Ma X, Flomenberg N, Lisant MP, Pestell RG: c-Jun induces mammary epithelial cellular invasion and breast cancer stem cell expansion. J Biol Chem 2010, 285: 8218-8226

69. Martini SR, Roman G, Meuser S, Mardon G, Davis RL: The retinal determination gene, dachshund, is required for mushroom body cell differentiation. Development 2000, 127:2663-2672
70. Popov VM, Zhou J, Shirley LA, Quong J, Yeow WS, Wright JA, Wu K Rui H, Vadlamudi RK, Jiang J, Kumar R, Wang C, Pestell RG: The cell fate determination factor $\mathrm{DACH} 1$ is expressed in estrogen receptor-alpha-positive breast cancer and represses estrogen receptor-alpha signaling. Cancer Res 2009, 69:5752-5760

71. Wu K, Katiyar S, Witkiewicz A, Li A, McCue P, Song LN, Tian L, Jin M, Pestell RG: The cell fate determination factor dachshund inhibits androgen receptor signaling and prostate cancer cellular growth Cancer Res 2009, 69:3347-3355

72. Popov VM, Wu K, Zhou J, Powell MJ, Mardon G, Wang C, Pestell RG The dachshund gene in development and hormone-responsive tumorigenesis. Trends Endocrinol Metab 2010, 21:41-49

73. Zhou J, Wang C, Wang Z, Dampier W, Wu K, Casimiro MC, Chepelev I, Popov VM, Quong A, Tozeren A, Zhao K, Lisanti MP, Pestell RG: Attenuation of Forkhead signaling by the retinal determination factor DACH1. Proc Natl Acad Sci USA 2010, 107:6864-6869

74. Wu K, Li A, Rao M, Liu M, Dailey V, Yang Y, Di Vizio D, Wang C Lisanti MP, Sauter G, Russell RG, Cvekl A, Pestell RG: DACH1 is a cell fate determination factor that inhibits cyclin D1 and breast tumor growth. Mol Cell Biol 2006, 26:7116-7129

75. Wu K, Jiao X, Li Z, Katiyar S, Casimiro MC, Yang W, Zhang Q, Willmarth NE, Chepelev I, Crosariol M, Wei Z, Hu J, Zhao J, Pestell RG: The cell fate determination factor dachshund reprograms breas cancer stem cell function. J Biol Chem 2011, 286:2132-2142

76. Wu K, Katiyar S, Li A, Liu M, Ju X, Popov VM, Jiao X, Lisanti MP Casola A, Pestell RG: Dachshund inhibits oncogene-induced breast cancer cellular migration and invasion through suppression of interleukin-8. Proc Natl Acad Sci USA 2008, 105:6924-6929

77. Hayden MS, Ghosh S: Signaling to NF-kappaB. Genes Dev 2004 18:2195-2224

78. Karin M: The beginning of the end: IkappaB kinase (IKK) and NFkappaB activation. J Biol Chem 1999, 274:27339-27342

79. Cogswell PC, Guttridge DC, Funkhouser WK, Baldwin AS Jr: Selective activation of NF-kappa B subunits in human breast cancer: potential roles for NF-kappa B2/p52 and for Bcl-3. Oncogene 2000 19:1123-1131

80. Pratt MA, Bishop TE, White D, Yasvinski G, Ménard M, Niu MY Clarke R: Estrogen withdrawal-induced NF-kappaB activity and bcl-3 expression in breast cancer cells: roles in growth and hormone independence. Mol Cell Biol 2003, 23:6887-6900

81. Liu M, Ju X, Willmarth NE, Casimiro MC, Ojeifo J, Sakamaki T, Katiyar S, Jiao X, Popov VM, Yu Z, Wu K, Joyce D, Wang C, Pestell RG: Nuclear factor-kappaB enhances ErbB2-induced mammary tumorigenesis and neoangiogenesis in vivo. Am J Pathol 2009, 174:19101920

82. Sliva D, English D, Lyons D, Lloyd FP Jr: Protein kinase C induces motility of breast cancers by upregulating secretion of urokinasetype plasminogen activator through activation of AP-1 and NF-kappaB. Biochem Biophys Res Commun 2002, 290:552-557

83. Beshir AB, Ren G, Magpusao AN, Barone LM, Yeung KC, Fenteany G: Raf kinase inhibitor protein suppresses nuclear factor-kappaBdependent cancer cell invasion through negative regulation of matrix metalloproteinase expression. Cancer Lett 2010, 299:137-149

84. Velasco-Velázquez MA, Yu Z, Jiao X, Pestell RG: Cancer stem cells and the cell cycle: targeting the drive behind breast cancer. Expert Rev Anticancer Ther 2009, 9:275-279

85. Valastyan S, Weinberg RA: MicroRNAs: crucial multi-tasking components in the complex circuitry of tumor metastasis. Cell Cycle 2009, 8:3506-3512

86. Shi M, Liu D, Duan H, Shen B, Guo N: Metastasis-related miRNAs, active players in breast cancer invasion, and metastasis. Cance Metastasis Rev 2010, 29:785-799

87. Yu Z, Wang C, Wang M, Li Z, Casimiro MC, Liu M, Wu K, Whittle J Ju X, Hyslop T, McCue P, Pestell RG: A cyclin D1/microRNA 17/20 regulatory feedback loop in control of breast cancer cell proliferation. J Cell Biol 2008, 182:509-517

88. Yu Z, Willmarth NE, Zhou J, Katiyar S, Wang M, Liu Y, McCue PA, Quong AA, Lisanti MP, Pestell RG: microRNA 17/20 inhibits cellular invasion and tumor metastasis in breast cancer by heterotypic sig naling. Proc Natl Acad Sci USA 2010, 107:8231-8236

89. Stahl M, Ge C, Shi S, Pestell RG, Stanley P: Notch1-induced transformation of RKE-1 cells requires up-regulation of cyclin D1. Cance Res 2006, 66:7562-7570 
90. Lindsay J, Jiao X, Sakamaki T, Casimiro MC, Shirley LA, Tran TH, Ju X, Liu M, Li Z, Wang C, Katiyar S, Rao M, Allen KG, Glazer RI, Ge C, Stanley P, Lisanti MP, Rui H, Pestell RG: ErbB2 induces Notch1 activity and function in breast cancer cells. Clin Transl Sci 2008, 1:107-115

91. Ling H, Sylvestre JR, Jolicoeur P: Notch1-induced mammary tumor development is cyclin D1-dependent and correlates with expansion of pre-malignant multipotent duct-limited progenitors. Oncogene 2010, 29:4543-4554

92. Li Z, Wang C, Prendergast GC, Pestell RG: Cyclin D1 functions in cell migration. Cell Cycle 2006, 5:2440-2442

93. Korpal M, Lee ES, Hu G, Kang Y: The miR-200 family inhibits epithelial-mesenchymal transition and cancer cell migration by direct targeting of E-cadherin transcriptional repressors ZEB1 and ZEB2. J Biol Chem 2008, 283:14910-14914

94. Park SM, Gaur AB, Lengyel E, Peter ME: The miR-200 family determines the epithelial phenotype of cancer cells by targeting the E-cadherin repressors ZEB1 and ZEB2 [Erratum appeared in Genes Dev 2009;23:1378]. Genes Dev 2008, 22:894-907

95. Burk U, Schubert J, Wellner U, Schmalhofer O, Vincan E, Spaderna $\mathrm{S}$, Brabletz T: A reciprocal repression between ZEB1 and members of the miR-200 family promotes EMT and invasion in cancer cells. EMBO Rep 2008, 9:582-589

96. Wellner U, Schubert J, Burk UC, Schmalhofer O, Zhu F, Sonntag A, Waldvogel B, Vannier C, Darling D, zur Hausen A, Brunton VG Morton J, Sansom O, Schüler J, Stemmler MP, Herzberger C, Hopt U, Keck T, Brabletz S, Brabletz T: The EMT-activator ZEB1 promotes tumorigenicity by repressing stemness-inhibiting microRNAs. Nat Cell Biol 2009, 11:1487-1495

97. Hermann PC, Huber SL, Herrler T, Aicher A, Ellwart JW, Guba M, Bruns CJ, Heeschen C: Distinct populations of cancer stem cells determine tumor growth and metastatic activity in human pancreatic cancer. Cell Stem Cell 2007, 1:313-323
98. Tsimberidou AM, Giles FJ, Estey E, O'Brien S, Keating MJ, Kantarjian HM: The role of gemtuzumab ozogamicin in acute leukaemia therapy. Br J Haematol 2006, 132:398-409

99. Ozben T: Mechanisms and strategies to overcome multiple drug resistance in cancer. FEBS Lett 2006, 580:2903-2909

100. Riccioni R, Dupuis ML, Bernabei M, Petrucci E, Pasquini L, Mariani G, Cianfriglia M, Testa U: The cancer stem cell selective inhibitor salinomycin is a p-glycoprotein inhibitor. Blood Cells Mol Dis 2010, 45:86-92

101. Gupta PB, Onder TT, Jiang G, Tao K, Kuperwasser C, Weinberg RA, Lander ES: Identification of selective inhibitors of cancer stem cells by high-throughput screening. Cell 2009, 138:645-659

102. Feldmann G, Fendrich V, McGovern K, Bedja D, Bisht S, Alvarez H, Koorstra JB, Habbe N, Karikari C, Mullendore M, Gabrielson KL, Sharma R, Matsui W, Maitra A: An orally bioavailable smallmolecule inhibitor of Hedgehog signaling inhibits tumor initiation and metastasis in pancreatic cancer. Mol Cancer Ther 2008, 7:2725-2735

103. Ma L, Reinhardt F, Pan E, Soutschek J, Bhat B, Marcusson EG Teruya-Feldstein J, Bell GW, Weinberg RA: Therapeutic silencing of miR-10b inhibits metastasis in a mouse mammary tumor model. Nat Biotechnol 2010, 28:341-347

104. Platt VM, Szoka FC Jr: Anticancer therapeutics: targeting macromolecules and nanocarriers to hyaluronan or CD44, a hyaluronan receptor. Mol Pharm 2008, 5:474-486

105. Jin L, Hope KJ, Zhai Q, Smadja-Joffe F, Dick JE: Targeting of CD44 eradicates human acute myeloid leukemic stem cells. Nat Med 2006, 12:1167-1174

106. Ginestier C, Liu S, Diebel ME, Korkaya H, Luo M, Brown M, Wicinski J, Cabaud O, Charafe-Jauffret E, Birnbaum D, Guan JL, Dontu G, Wicha MS: CXCR1 blockade selectively targets human breast cancer stem cells in vitro and in xenografts. J Clin Invest 2010, 120 485-497 